Lesław KYZIOŁ, Włodzimierz KOŃCZEWICZ, Adrian DYNOWSKI

Gdynia Maritime University (Uniwersytet Morski w Gdyni)

\title{
THE ANALYSIS OF THE POSSIBILITIES OF USING 3D PRINTER FOR MAKING COMPONENTS AND PARTS OF MARINE EQUIPMENT FOR EXAMPLE FLEXIBLE CLUTCH COUPLING
}

\author{
Analiza możliwości wykorzystania drukarki 3D \\ do wytwarzania elementów i części urządzeń okrętowych
}

\begin{abstract}
The advantage of incremental techniques is the reduction of material losses as opposed to loss techniques, i.e. machining. The element of flexible insert of the flexible coupling was made with the use of the incremental technique using the FDM method made of ABS plastic and the exploitation tests of the performed insert were performed in the device simulating the operation of the thruster on the ship. The use of materials obtained from the recycling of plastic waste is of great importance for printing.

Keywords: 3D printer, methods of incremental techniques, materials for printers, flexible couplings.

Streszczenie: Zaletą technik przyrostowych jest zmniejszenie strat materiałowych w odróżnieniu do technik ubytkowych tj. obróbki skrawaniem. Technika przyrostowa wykonano element wktadki elastycznej sprzegła podatnego za pomoca metody FDM z tworzywa ABS i przeprowadzono badania eksploatacyjne wykonanej wkładki w urządzeniu symulujacym działanie steru strumieniowego na statku. Duże znaczenie ma wykorzystanie do druku materiałów uzyskanych z recyklingu odpadów z tworzyw sztucznych.
\end{abstract}

Słowa kluczowe: drukarka 3D, metody technik przyrostowych, materiały do drukarek, wkładki elastyczne sprzęgieł 


\section{Introduction}

3D printing is a method of making elements, parts of mechanisms layer by layer. The method was initiated in 1984 by the American Charles Hull, who created stereolithography. This method requires the use of light and a curable resin. The laser beam hardens the resin in selected places according to the operator's requirements. After the manufacturing process, a spatial object is created. Technological development of the production of elements with this method focused mainly on the development of new materials and methods for the production of socalled incremental $[2,8]$.

The additive (incremental) technique is an alternative to waste techniques (machining), where a considerable amount of material is removed from the material to produce an element of the intended shape. This is one of the advantages of $3 \mathrm{D}$ printing that you use the amount of building material that is needed to create an element without any machining allowances. Layer-by-layer production itself allows you to create elements with considerably complex structures that are either not feasible or simply the cost of manufacturing is too high [8].

There are many methods of creating incremental techniques, the fundamental difference between the processes of creating an element with 3D printing results from the type of material used and the method of applying subsequent layers. One of the methods is SLA (Stereolithography). In this method, the material is obtained by means of a UV laser beam for local photo-curing of the resin. The resulting material is immersed in a tank with liquid resin. The layers are created as a result of deeper immersion of the created elements in the tank with acrylic or epoxy resin. The first layer is placed slightly below the liquid level. Polymerization occurs due to the energy of the UV laser beam, the source of which is located above the tank. After hardening of the applied layer, the process is repeated by applying successive layers and hardening them until the intended geometry of the element, based on the computer model, is achieved. The production process using this method is shown in fig. $1[8]$. 


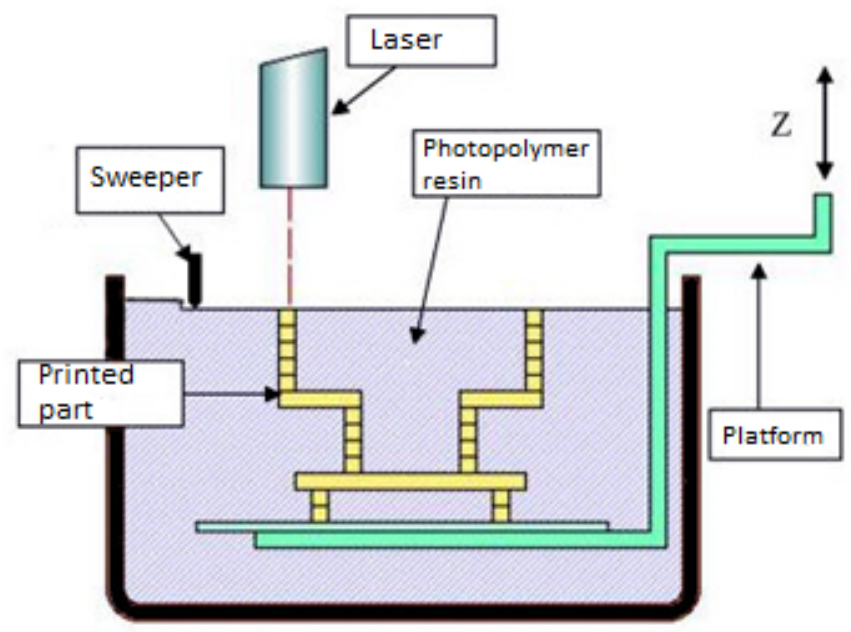

Fig. 1. Stereolitography creating proces

The FDM (Fused Deposition Modeling) method is based on extruding semiliquid materials. In this method, thermoplastics are used, which are extruded through a nozzle and applied layer by layer. The FDM method is widely used, due to the wide range of materials used, as well as the availability of simple devices for production using this method. The FDM process is shown in fig. 2 [8].

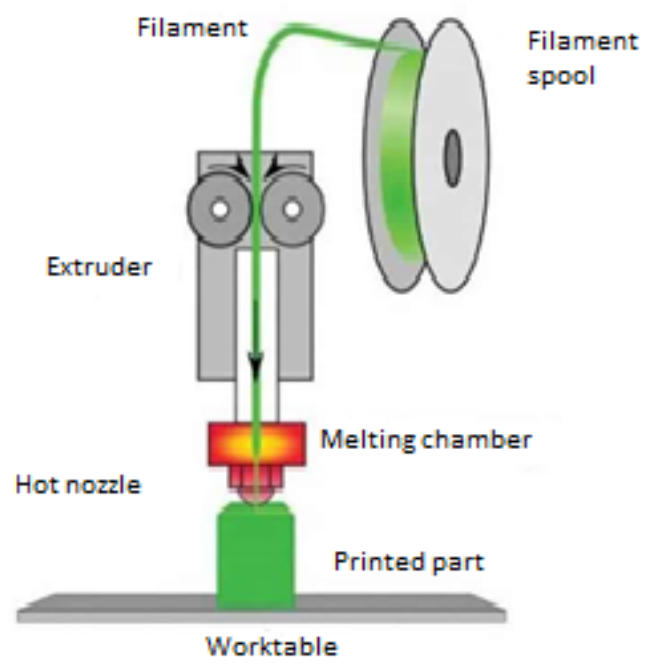

Fig. 2. FDM creating proces 
In contrast, the SLS (Selective Laser Sintering) method concerns selective laser sintering of powders from different materials, the source of heat in this method is a laser beam. Sintering consists in combining material particles in the form of a powder by melting them. The pulverized material is a spotting laser beam and the unhardened one is removed and reused [8].

\section{Material research}

Thermoplastic materials adapted for spatial printing such as PLA (polyactide) and ABS (acrylonitrile-butadiene-styrene) were tested. Samples for testing were made with the 3DGence One 3D printer with Simplify3D software [3, 4]. The tensile strength of the tested materials was carried out on a universal testing machine with hydraulic drive type MPMD P10B with the TestXpert II software in version 3.61 from Zwick \& Roell together with the extensometer Epsilon model $3542[1]$.

The tests were carried out on PLA and ABS materials. The aim of the research was to determine the tensile strength of materials depending on the density (degree of filling). The degree of honeycomb filling ranged from $20 \%$ to $100 \%$ and also in order to choose the right material for making the elastic insert of the flexible coupling.

a)

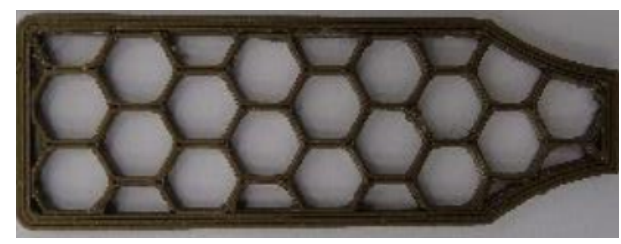

b)

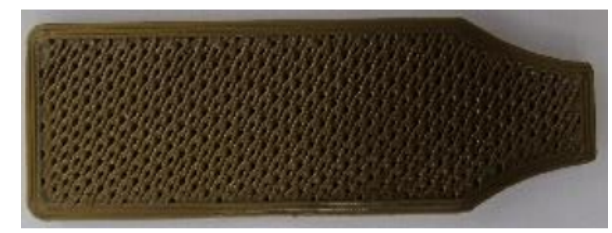

Fig. 3. The degree of honeycomb filling with thermoplastic materials a) $20 \%$, b) $100 \%$

For illustrative purposes, fig. 3 shows, for example, a honeycomb filled with $20 \%$ - fig. $3 \mathrm{a}$ and $100 \%$ - fig. $3 \mathrm{~b}$ of a thermoplastic material. Materials were made for strength tests. The shape and dimensions of the samples are shown in fig. 4 [6]. Fig. 5 the image of the samples for the static tensile test is presented. 


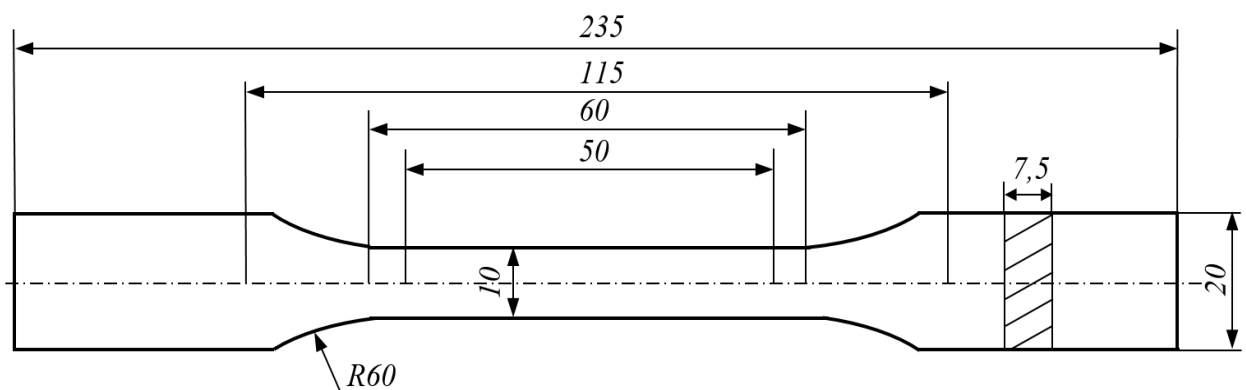

Fig. 4. The shape and dimensions of samples for static tensile tests

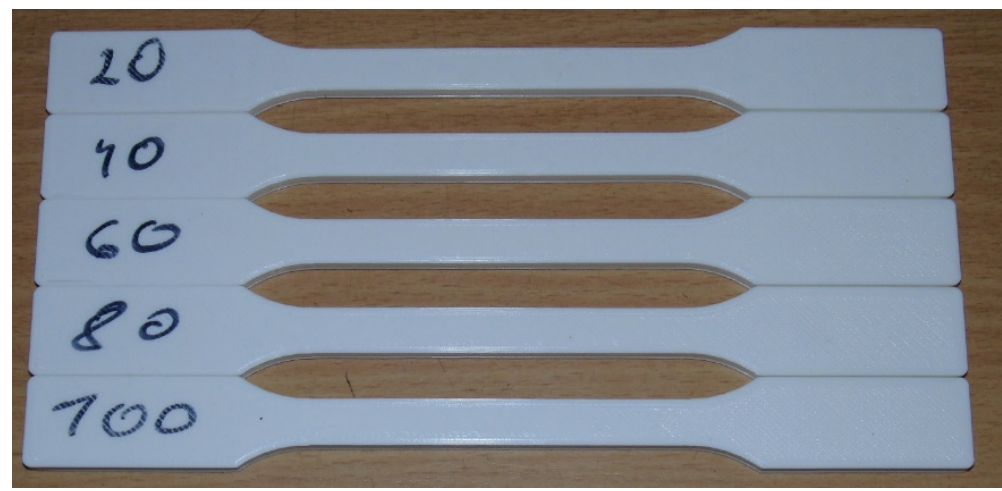

Fig. 5. Image of samples made of PLA material for static tensile tests

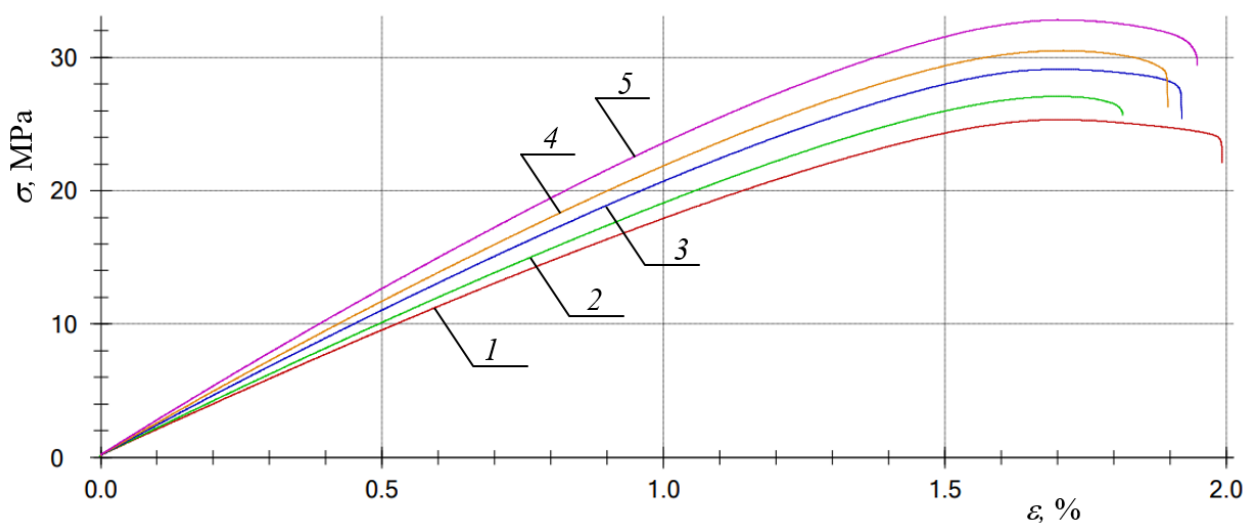

Fig. 6. Plotting graphs of PLA samples depending on the degree of filling $(1-20 \%, 2-$ $40 \%, 3-60 \%, 4-80 \%, 5-100 \%$ filling) 
Fig. 6 presents graphs of a static tensile test of samples from PLA materials with different the degree of filling. The graphs show that with increasing material density, its strength and plastic properties increase [2].

The results of mechanical tests allowed selection of a material with a certain degree of filling to make squeegee couplings. The samples were made of PLA material with a $100 \%$ fill with the following printing parameters set in the Simplify3D software for a given material $[3,4]$ :

- temperature of the printing nozzle:

- for first layer: $215^{\circ} \mathrm{C}$;

- for rest layers: $210^{\circ} \mathrm{C}$,

- worktable temperature:

- for layers from first to fourth: $75^{\circ} \mathrm{C}$;

- for layers from fifth to the rest: $70^{\circ} \mathrm{C}$,

- printing speed: $50 \mathrm{~mm} / \mathrm{s}$,

- layer hight: $0,1 \mathrm{~mm}$,

- cooling speed:

- for layers from first to fourth: $0 \%$ power,

- for layers from fifth and the rest: $100 \%$ power.

Similar strength tests were carried out for the ABS material.

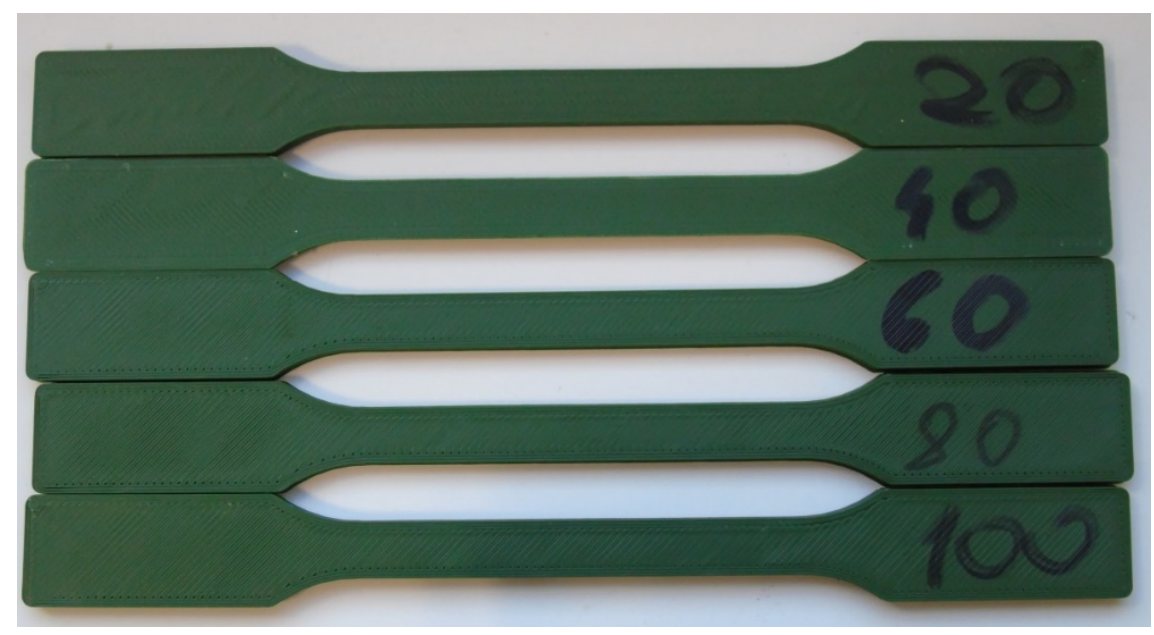

Fig. 7. Sample images made of ABS material for static tensile testing

Fig. 7 shows the images of samples for static tensile tests. 


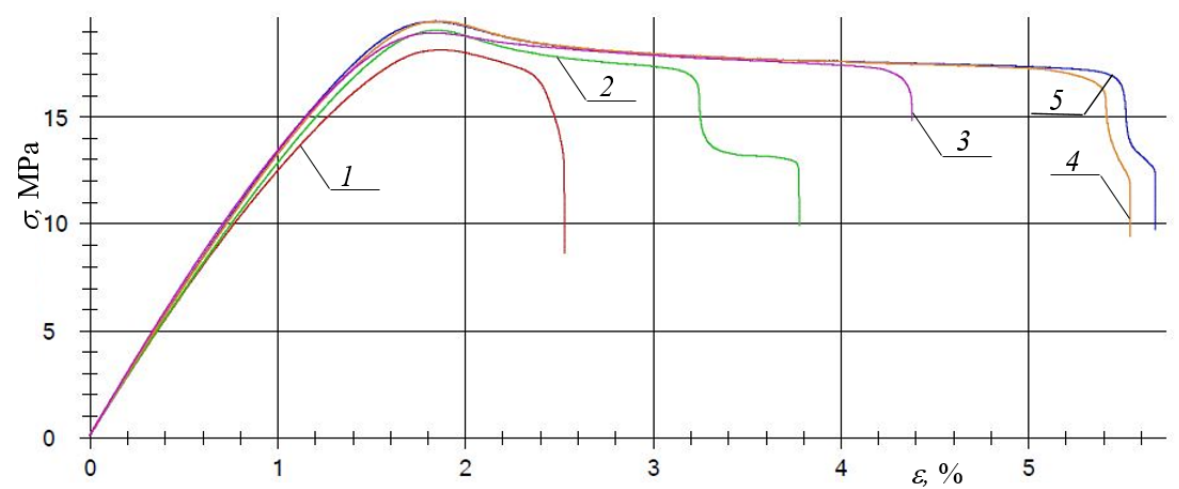

Fig. 8. Plotting graphs of ABS samples depending on the degree of filling $(1-20 \%, 2-$ $40 \%, 3-60 \%, 4-80 \%, 5-100 \%$ filling)

Fig. 8 presents graphs of a static tensile test of samples made of ABS materials with different filling degree. The course of the graphs shows that the increase in material density does not substantially affect its strength properties. However, its artistic properties change. The highest plasticity was shown by material with a $100 \%$ degree filling, while the lowest plasticity was demonstrated by a material with a $20 \%$ degree of filling [2].

The results of mechanical tests allowed the selection of a material with a certain degree of filling to make the inserts for the coupling. For producing printed samples, ABS material with a $100 \%$ filling density has been used with the following printing parameters set in the Simplify3D software for a given material $[3,4]$ :

- temperature of the printing nozzle:

- for all layers: $245^{\circ} \mathrm{C}$,

- worktable temperature:

- for all layers: $90^{\circ} \mathrm{C}$,

- printing speed: $40 \mathrm{~mm} / \mathrm{s}$,

- layer hight: $0,1 \mathrm{~mm}$,

- cooling speed:

- for layers from first to fourth: $0 \%$ power,

- for fifth layer: $20 \%$ power,

- for sixth and rest layers: $12 \%$ power.

ABS material (acrylonitrile-butadiene-styrene) was selected for printing the flexible elastic coupling. The material was chosen for exhibiting unchanging strength from the density of the filling and increase in plasticity with increasing density of the filling. 


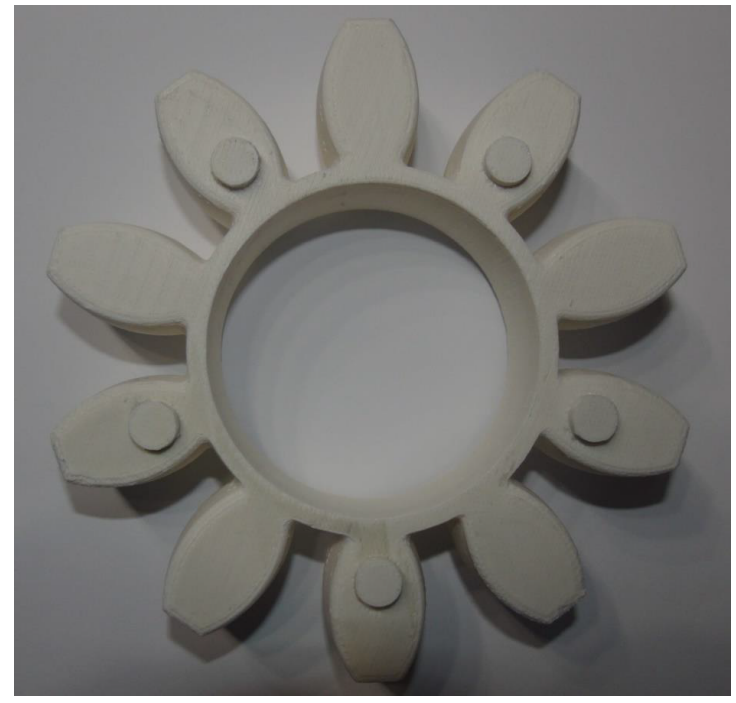

Fig. 9. Image of a flexible coupling insert made with 3D printing

Fig. 9 shows the image of the claw coupling insert made with 3D printing from ABS material.

\section{Exploitation research}

The next stage of the work was to test the insert in the claw coupling $[2,5]$. The clutch with the insert has been subjected to operational tests. It was installed in the simulation station of the spin-test drive.

The claw cylinder insert made was made of ABS material with $100 \%$ density, because using a lower density insert will reduce the stiffness of the entire insert. The hardness value of ABS material in the Shore type D scale was 81 [7]. Hardness measurement was made using an instrument called a durometer to measure the hardness of non-metallic materials.

The exploitation trials of printed inserts were carried out at the headquarters of the Rolls-Royce company in Gdynia. The inserts were tested in a device simulating the work of a bow thruster (fig. 9). It was placed in the helical clutch of the TV150 thruster transferring the torque from the electric motor to the vertical shaft. The rotational speed of the shaft was $670 \mathrm{rpm}$. The tests allowed observation of the coupling operation with the insert under normal operating conditions. Operational tests lasted 4 hours, the insert was inspected every 0.5 hour. 


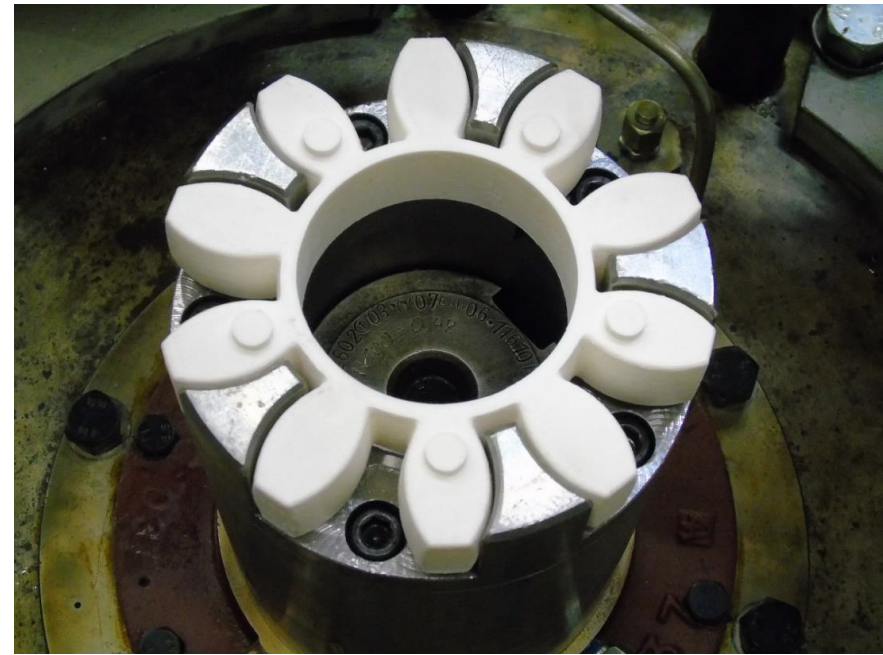

Fig. 10. Elastic clutch insert flexible in the hub

Fig. 10 shows the mounted insert in the claw coupling. The exploitation test showed a high absorption of vibrations generated by the electric motor, the amplitude of the vibrations of the insert printed with the FDM method was slightly higher compared to the insert made traditionally. No visible changes in the functioning of the device were observed despite the high stiffness and hardness of the insert. A slight increase in temperature during the test was observed, which did not affect the wear and strength of the insert made with the FDM method.

\section{Summary}

The tests and tests of materials for 3D printing allowed for their initial assessment of the use for spatial printing in order to manufacture elements of equipment and machines in shipbuilding.

Mechanical tests have shown that in the case of PLA material, the strength increases with increasing density of the fill, without changing the plasticity. The ABS material showed unchanged strength from the density of the filling and increase in plasticity with the increase in density of the filling. Research on materials should be continued.

The exploitation trials confirmed the advantages of $3 \mathrm{D}$ printing used to manufacture elements necessary for the operation of machines. 
The use of plastics causes most of the resistance to chemicals and lack of susceptibility to corrosion, which increases the service life of device elements in relation to parts made of metal alloys.

Making elements and machine parts with incremental techniques allows parts to be manufactured especially in emergency situations.

\section{References}

1. Dokumentacja Techniczno Ruchowa urządzenia wytrzymałościowego MPMD P10B.

2. Dynowski A.: Analiza możliwości wykorzystania drukarki 3D do wytwarzania elementów i części urządzeń okrętowych na przykładzie wkładki do sprzęgła kłowego, Praca dyplomowa, Gdynia 2018.

3. http://3dgence.com/drukarka-one/ (dostęp 21.03.2019).

4. Instrukcja obsługi drukarki 3DGence One.

5. Kyzioł L.: Podstawy konstrukcji maszyn, cz. II, AMW, Gdynia 2008.

6. PN-EN ISO 527-1 - Oznaczenie własności mechanicznych przy statycznym rozciąganiu Część 1: Zasady ogólne.

7. PN-ISO 868:2005 - Oznaczenie twardości metodą wciskania $\mathrm{z}$ zastosowaniem twardościomierza.

8. Siemiński P., Budzik G.: Techniki Przyrostowe. Druk 3D. Drukarki 3D, Wydawnictwo OWPW, Warszawa 2015. 


\section{ANALIZA MOŻLIWOŚCI WYKORZYSTANIA DRUKARKI 3D DO WYTWARZANIA ELEMENTÓW I CZĘŚCI URZĄDZEŃ OKRĘTOWYCH}

\section{Wprowadzenie}

Druk 3D jest to metoda wytwarzania elementów, części mechanizmów warstwa po warstwie. Metoda została zapoczątkowana w 1984 roku przez Amerykanina Charlesa Hulla, który stworzył stereolitografię. Wymaga ona zastosowania światła i żywicy utwardzalnej. Wiązka lasera powoduje utwardzanie żywicy w wybranych miejscach zgodnie $\mathrm{z}$ wymaganiami operatora. Po procesie wytwarzania powstaje obiekt przestrzenny. Rozwój technologiczny wytwarzania elementów tą metodą zasadniczo skupił się na opracowaniu nowych materiałów i metod wytwarzania tzw. przyrostowego $[2,8]$.

Technika addytywna (przyrostowa) jest alternatywą dla technik ubytkowych (obróbka skrawaniem), gdzie z materiału zostaje usunięta znaczna ilość materiału $\mathrm{w}$ celu wykonania elementu o zamierzonym kształcie. Jest to jedna $\mathrm{z}$ zalet druku 3D, że wykorzystuje się taką ilość materiału budulcowego, jaka jest potrzebna do otrzymania elementu bez żadnych naddatków na obróbkę. Samo układanie materiału warstwa po warstwie pozwala tworzyć elementy o znacznie skomplikowanych konstrukcjach, które tradycyjnymi metodami nie byłyby wykonalne lub po prostu koszt wytworzenia byłby zbyt wysoki [8].

Istnieje wiele metod wytwarzania technikami przyrostowymi. Różnica pomiędzy procesami tworzenia elementu drukiem 3D wynika z rodzaju zastosowanego materiału oraz sposobu nanoszenia kolejnych warstw. Jedną z nich jest SLA czyli stereolitografia. W metodzie tej materiał jest otrzymywany za pomocą miejscowego fotoutwardzenia żywicy przez wiązki lasera UV. Tworzony materiał jest zanurzany w zbiorniku z ciekłą żywicą. Warstwy powstają w wyniku głębszego zanurzenia się wytworzonego elementy $\mathrm{w}$ zbiorniku z żywicą akrylową lub epoksydową. Pierwsza warstwa umieszczona jest minimalnie pod poziomem cieczy. Polimeryzacja zachodzi dzięki energii wiązki lasera UV, której źródło umieszczone jest nad zbiornikiem. Po utwardzeniu nałożonej warstwy proces zostaje powtórzony przez nałożenie kolejnych warstw i utwardzeniu ich aż do 
osiągnięcia zamierzonej geometrii elementu, którego bazą jest model komputerowy. Proces wytwarzania metodą SLA przedstawiono na rys. 1 [8].

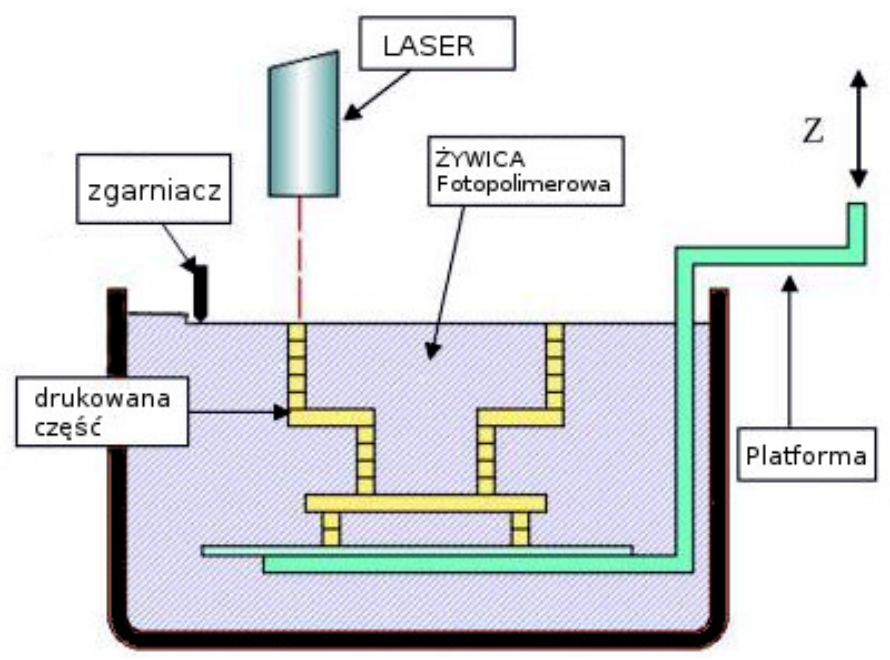

Rys. 3. Proces wytwarzania metodą SLA

Metoda FDM (Fused Deposition Modeling) opiera się na wytłaczaniu materiałów półpłynnych. Wykorzystywane są w niej tworzywa sztuczne termoplasty, które wytłaczane są przez dyszę i nanoszone warstwa po warstwie Metoda FDM jest powszechnie stosowana, ze względu na szeroki zakres używanych materiałów, a także na dostępność prostych urządzeń do jej wytwarzania. Proces tworzenia metodą FDM przedstawiono poniżej (rys. 2) [8].

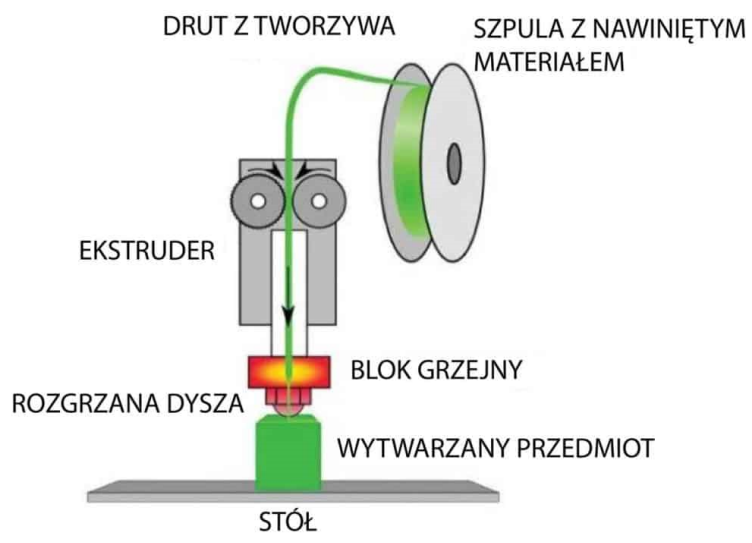

Rys. 4. Proces wytwarzania metodą FDM 
Natomiast metoda SLS (Selective Laser Sintering) dotyczy selektywnego spiekania laserowego proszków z różnych materiałów, źródłem ciepła w tej metodzie jest wiązka lasera. Spiekanie polega na łączeniu drobinek materiału w postaci proszku poprzez ich nadtapianie. Sproszkowany materiał jest nadtopiony punktowo wiązką lasera a nieutwardzony pozostaje usunięty i ponownie wykorzystany [8].

\section{Badania materialowe}

Badaniom poddano materiały termoplastyczne przystosowane do wydruku przestrzennego, jakimi są PLA (poliaktyd) i ABS (akrylonitrlo-butadienostyren). Próbki do badań zostały wykonane dzięki drukarce przestrzennej 3DGence One z oprogramowaniem Simplify3D [3, 4]. Wytrzymałość na rozciąganie badanych materiałów przeprowadzono na uniwersalnej maszynie wytrzymałościowej z napędem hydraulicznym typ MPMD P10B z oprogramowaniem TestXpert II w wersji 3.61 firmy Zwick\&Roell wraz z ekstensometrem Epsilon model 3542 [1].

Celem badań było określenie wytrzymałości na rozciąganie materiałów PLA i ABS w zależności od gęstości (stopnia wypełnienia) materiału. Stopień wypełnienia plastra miodu wynosił od $20 \%$ do $100 \%$, a także w celu dobrania odpowiedniego materiału na wykonanie wkładki elastycznej sprzęgła podatnego.

a)

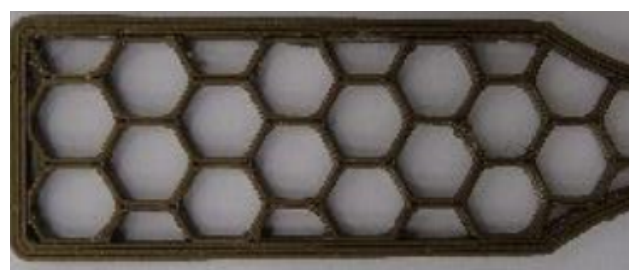

b)

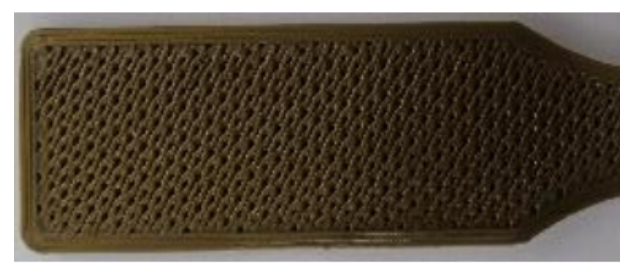

Rys. 3. Stopień wypełnienia materiałami termoplastycznymi plastra: a) $20 \%$, b) $100 \%$

W celach poglądowych na rys. 3 przedstawiono przykładowo plaster miodu wypełniony $20 \%$ - rys. 3 a i $100 \%$ - rys. 3 b materiałem termoplastycznym. $\mathrm{Z}$ materiałów wykonano próbki do badań wytrzymałościowych. Kształt i wymiary próbek przedstawiono na rys. 4 [6]. Na rys. 5 przedstawiono obraz próbek do badań statycznej próby rozciągania. 


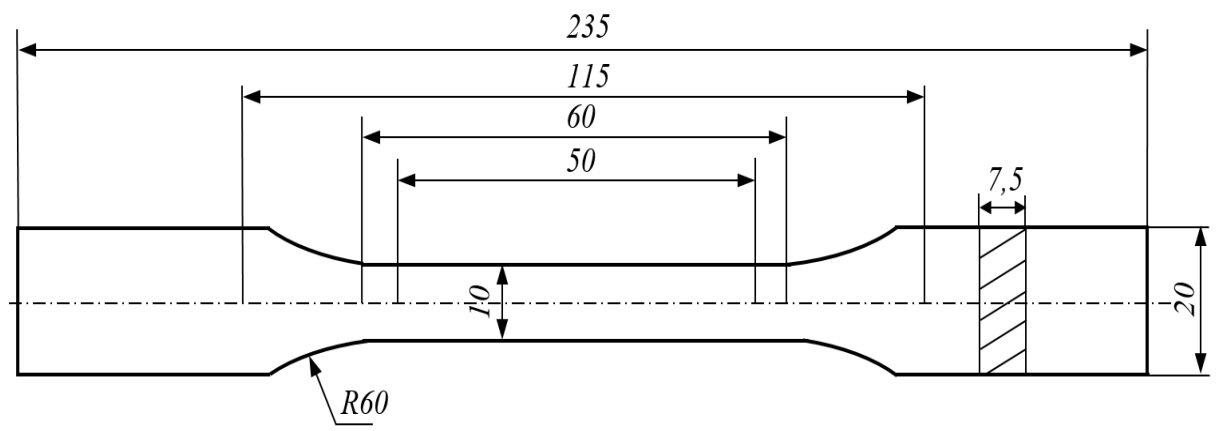

Rys. 4. Kształt i wymiary próbek do badań statycznej próby rozciągania

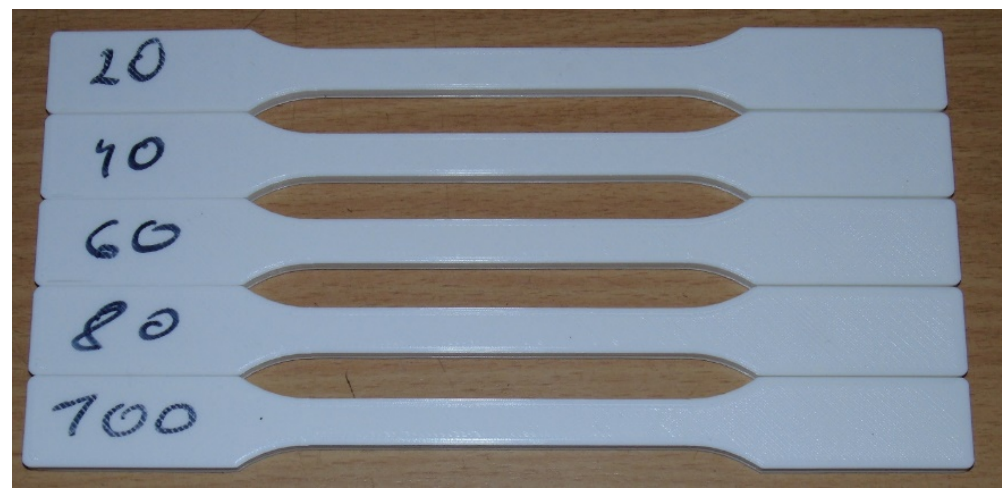

Rys. 5. Obraz próbek wytworzone z materiału PLA do badań statycznej próby rozciągania

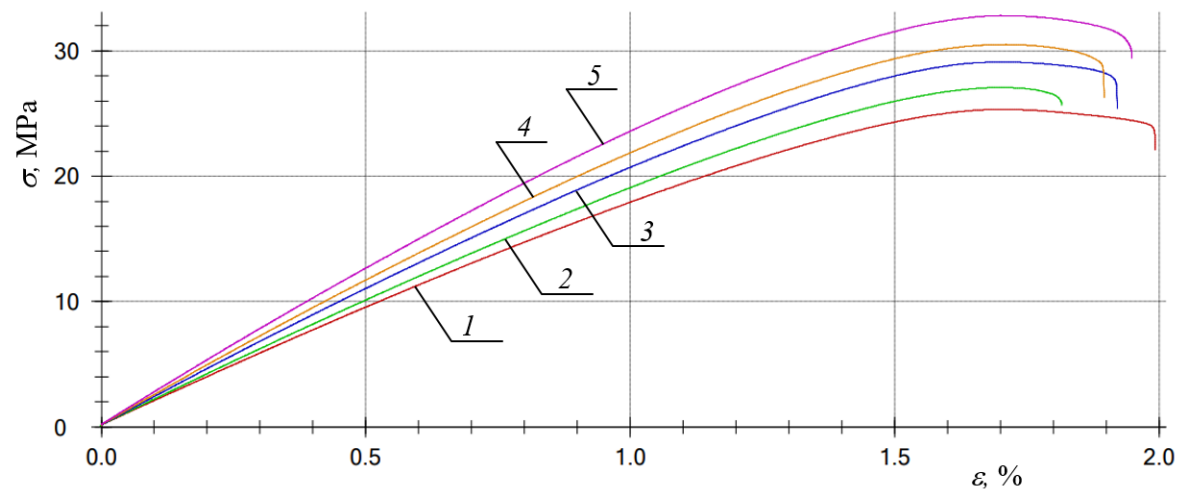

Rys. 6. Wykresy rozciągania próbek materiału PLA zależne od stopnia wypełniania (1 $20 \%$ wypełnienia, $2-40 \%$ wypełnienia, $3-60 \%$ wypełnienia, $4-80 \%$ wypełnienia, 5 - 100\% wypełnienia) 
Na rys. 6 przedstawiono wykresy statycznej próby rozciągania próbek z materiałów PLA o różnym stopniu wypełnienia. $Z$ wykresów wynika, że wraz ze wzrostem gęstości materiału wzrastają jego właściwości wytrzymałościowe i plastyczne [2].

Wyniki badań mechanicznych pozwoliły na dobór materiału o określonym stopniu wypełnienia do wykonania wkładek sprzęgieł podatnych. Próbki uzyskane z materiału PLA o wypełnieniu $100 \%$ o następujących parametrach drukowania ustawionych w oprogramowaniu Simplify3D dla danego materiału [3, 4]:

- temperatura dyszy drukującej:

- dla pierwszej warstwy: $215^{\circ} \mathrm{C}$;

- dla pozostałych warstw: $210^{\circ} \mathrm{C}$,

- temperatura stołu roboczego:

- dla warstw od pierwszej do czwartej: $75^{\circ} \mathrm{C}$;

- dla piątej warstwy: $70^{\circ} \mathrm{C}$,

- prędkość druku: $50 \mathrm{~mm} / \mathrm{s}$,

- grubość warstwy: $0,1 \mathrm{~mm}$,

- prędkość chłodzenia:

- dla warstw od pierwszej do czwartej: 0\% mocy,

- dla piątej warstwy: $100 \%$ mocy.

Podobne badania wytrzymałościowe przeprowadzono dla materiału ABS. Obrazy próbek do badań statycznej próby rozciągania ze wspomnianego maeriału przedstawiono na rys. 7 .

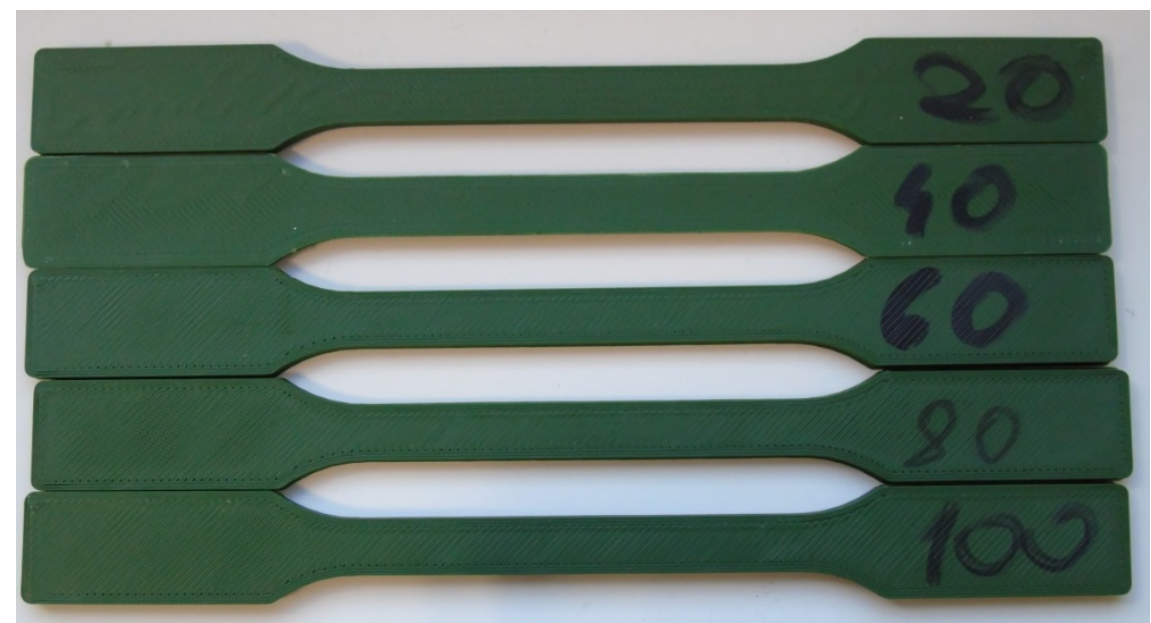

Rys. 7. Obrazy próbek wytworzone z materiału ABS do badań statycznej próby rozciągania 


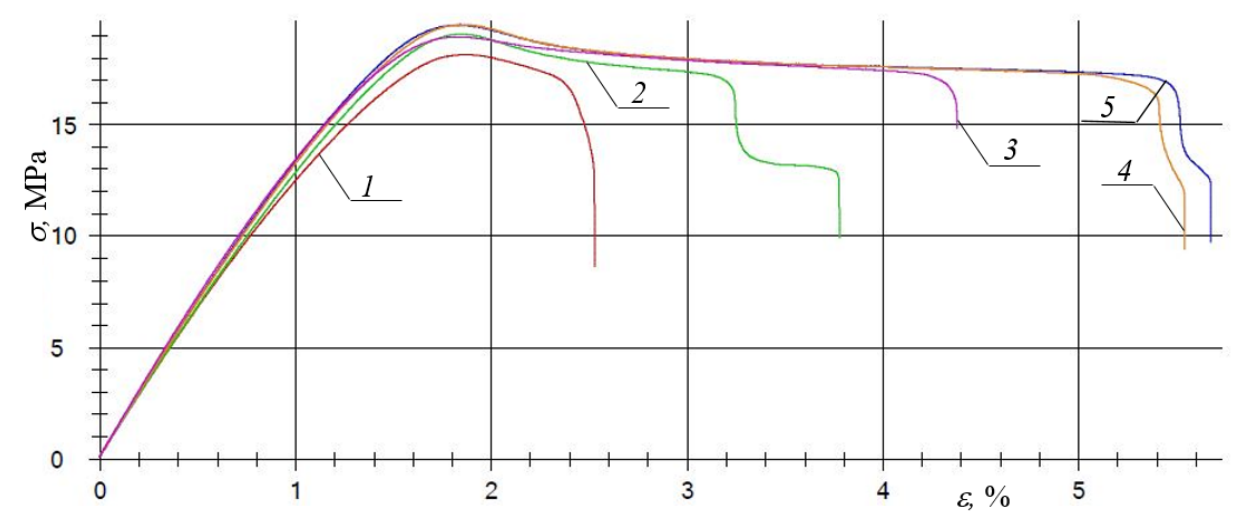

Rys. 8. Wykresy rozciągania próbek z materiału ABS zależne od stopnia wypełniania (1 $20 \%$ wypełnienia, $2-40 \%$ wypełnienia, $3-60 \%$ wypełnienia, $4-80 \%$ wypełnienia, 5 - 100\% wypełnienia)

Na rys. 8 przedstawiono wykresy statycznej próby rozciągania próbek z materiałów $\mathrm{ABS}$ o różnym stopniu wypełnienia. $Z$ przebiegu wykresów wynika, że wzrost gęstości materiału zasadniczo nie wpływa na jego właściwości wytrzymałościowe. Zmieniają się natomiast jego właściwości plastyczne. Największą plastycznością wykazał się materiał o 100\% stopniu wypełnienia, natomiast najniższą plastyczność wykazał się materiał o $20 \%$ stopniu wypełnienia [2].

Wyniki badań mechanicznych pozwoliły na dobór materiału o określonym stopniu wypełnienia do wykonania wkładek do sprzęgła. Do otrzymania próbek drukowanych zastosowano materiał ABS o gęstości wypełnienia $100 \%$ o następujących parametrach drukowania ustawionych w oprogramowaniu Simplify3D dla danego materiału $[3,4]$ :

- temperatura dyszy drukującej:

- dla wszystkich warstw: $245^{\circ} \mathrm{C}$,

- temperatura stołu roboczego:

- dla wszystkich warstw: $90^{\circ} \mathrm{C}$,

- prędkość druku: $40 \mathrm{~mm} / \mathrm{s}$,

- grubość warstwy: 0,1 mm,

- prędkość chłodzenia:

- dla warstw od pierwszej do czwartej: 0\% mocy,

- dla piątej warstwy: $20 \%$ mocy,

- dla szóstej warstwy: $12 \%$ mocy. 
Do drukowania wkładki elastycznej sprzęgła podatnego wybrano materiał ABS (akrylonitrlo-butadieno-styren). Materiał ten został wybrany ze względu na wykazywanie niezmiennej wytrzymałości od stopnia wypełnienia i wzrost plastyczności ze wzrostem stopnia wypełnienia.

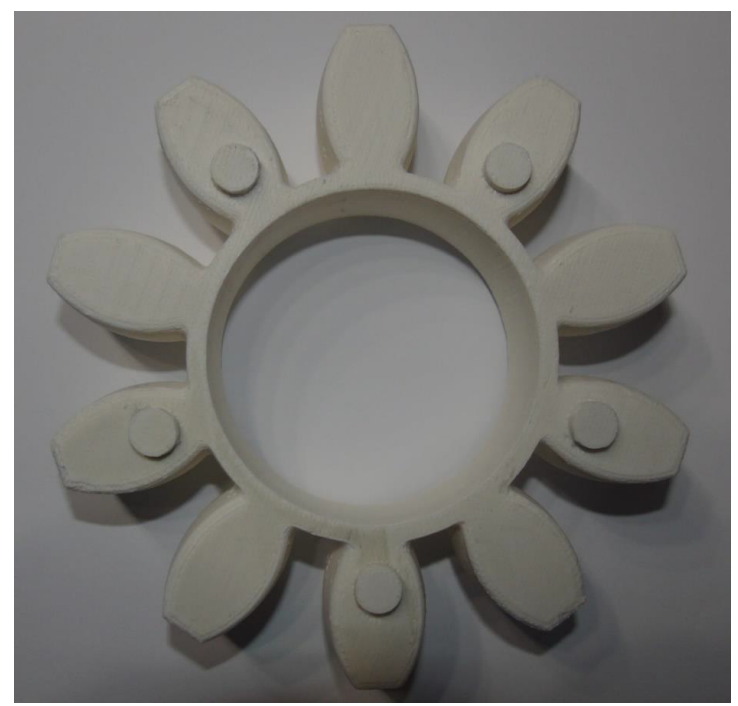

Rys. 9. Obraz wkładki sprzęgła podatnego wykonanej za pomocą druku 3D

Na rys. 9 przedstawiono obraz wkładki sprzęgła kłowego wykonanej za pomocą druku 3D z materiału ABS.

\section{Badania eksploatacyjne}

Następnym etapem pracy było przeprowadzenie badań wkładki w sprzęgle kołowym $[2,5]$. Sprzęgło z wkładką zostało poddane badaniom eksploatacyjnym. Zainstalowane je na stanowisku do symulacji napędu steru strumieniowego (SpinTest).

Wykonana wkładka do sprzęgła kłowego została pozyskana z materiału ABS o gęstości wypełnienia $100 \%$, ponieważ zastosowanie wkładki o niższe gęstości spowoduje obniżenie sztywności całej wkładki. Wartość twardości materiału ABS w skali Shore'a typu D wynosiła 81 [7]. Pomiar twardości został wykonany z użyciem przyrządu zwanego durometrem, służącym do pomiarów twardości materiałów niemetalowych. 
Próby eksploatacyjne wkładek drukowanych przeprowadzono w siedzibie firmy Rolls-Royce w Gdyni. Badane były w urządzeniu symulującym pracę steru strumieniowego (rys. 9). Umieszczono ją w sprzęgle kłowym steru strumieniowego TV150 przenoszącym moment obrotowy z silnika elektrycznego na wał pionowy. Prędkość obrotowa wału wynosiła $670 \mathrm{obr} / \mathrm{min}$. Próby pozwoliły na obserwację pracy sprzęgła $\mathrm{z}$ wkładką $\mathrm{w}$ normalnych warunkach pracy urządzenia. Badania eksploatacyjne trwały 4 godziny, co 0,5 godziny przeprowadzano oględziny wkładki.

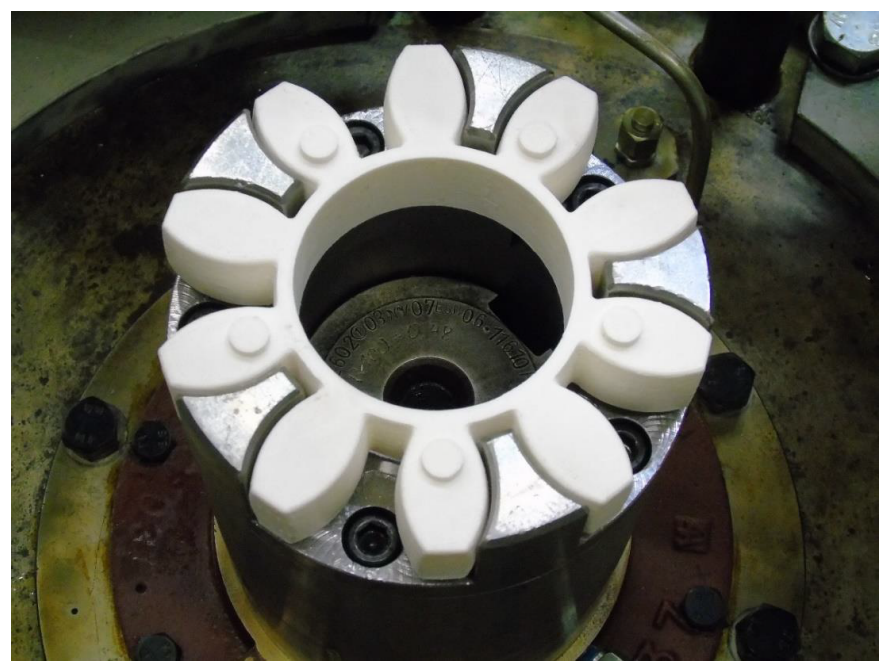

Rys. 10. Wkładka elastyczna sprzęgła podatnego w piaście

Na rys. 10 przedstawiono zamontowaną wkładkę w sprzęgle kłowym. Próba eksploatacyjna wykazała dużą absorpcję drgań wytwarzanych przez silnik elektryczny, amplituda występujących drgań wkładki wydrukowanej metodą FDM była nieznacznie większa w stosunku do wkładki wykonanej tradycyjnie. Nie zaobserwowano widocznych zmian w funkcjonowaniu urządzenia, pomimo dużej sztywności i twardości wkładki. Natomiast zaobserwowano nieznaczny wzrost temperatury podczas próby, która nie wpłynęła na zużycie i wytrzymałość wkładki wykonanej metodą FDM. 


\section{Podsumowanie}

Przeprowadzone badania i próby materiałów do druku 3D pozwoliły na wstępną ich ocenę zastosowania do wydruku przestrzennego w celu wytwarzania elementów urządzeń i maszyn w okrętownictwie.

Badania mechaniczne wykazały, że w przypadku materiału PLA wytrzymałość wzrasta wraz ze wzrostem gęstości wypełnienia, bez zmiany plastyczności. Materiał ABS wykazał niezmienną wytrzymałość od gęstości wypełnienia i wzrost plastyczności ze wzrostem gęstości wypełnienia. Badania odnośnie materiałów należy kontynuować.

Próby eksploatacyjne potwierdziły zalety druku 3D zastosowanego do wytwarzania elementów niezbędnych do funkcjonowania maszyn.

Zastosowanie tworzyw sztucznych powoduje większą odporność na działanie substancji chemicznych i brak podatności na korozję, przez co wzrasta żywotność elementów urządzeń w stosunku do części wytworzonych ze stopów metali.

Wykonywanie elementów i części maszyn technikami przyrostowymi pozwala na wytworzenia części szczególnie w sytuacjach awaryjnych.

\section{Literatura}

1. Dokumentacja Techniczno Ruchowa urządzenia wytrzymałościowego MPMD P10B.

2. Dynowski A.: Analiza możliwości wykorzystania drukarki 3D do wytwarzania elementów i części urząadzeń okrętowych na przykładzie wkładki do sprzęgła kłowego, Praca dyplomowa, Gdynia 2018.

3. http://3dgence.com/drukarka-one/ (dostęp 21.03.2019).

4. Instrukcja obsługi drukarki 3DGence One.

5. Kyzioł L.: Podstawy konstrukcji maszyn, cz. II, AMW, Gdynia 2008.

6. PN-EN ISO 527-1 - Oznaczenie własności mechanicznych przy statycznym rozciąganiu Część 1: Zasady ogólne.

7. PN-ISO 868:2005 - Oznaczenie twardości metodą wciskania $\mathrm{z}$ zastosowaniem twardościomierza.

8. Siemiński P., Budzik G.: Techniki Przyrostowe. Druk 3D. Drukarki 3D, Wydawnictwo OWPW, Warszawa 2015. 